\title{
Melbourne 1995
}

\author{
By Gerald Pratley
}

Fall 1995 Issue of KINEMA

WHAT A PLEASUR TO OPEN the catalogue of the 44th Melbourne International Film Festival to discover the absence of "welcoming messages" from the Prime Minister down to the local Mayor and introductions from the festival staff (complete with portraits) telling us how marvellous the program is and what great audiences we are!

Melbourne runs at exactly the same time as Sydney's film festival. No one quite seemed to know why, or to think that this was odd; after all, no one in Melbourne expected moviegoers to come from Sydney and none from Melbourne was expected by Sydney to attend its festival. So why not? There seems not to be any rivalry between the two, some films are shared, otherwise the programs are quite different - a likeably Australian relationship.

As 1995 marks the centenary of cinema it was fitting that Melbourne brought Australian films to the fore: the opening was the newly restored and tinted print of the classic The Sentimental Bloke, made in 1919 by Raymond Longford adapted from the book of verse by C. J. Dennis. The film created three screen characters who became instant folk heroes - the larrikin Bloke, his drinking mate Ginger Mick, and his "peach" Doreen. It is much loved by Australians, with good reason, being a true and touching depiction of themselves at a certain time in their history. This restoration was accompanied by the "live" performance of a score by Melbourne composer, Jen Anderson.

The closing film, the latest in a string of new and impressive Australian productions, was Alan Madden's Mushrooms, the blackest of black comedies, very clever, never coarse, about two eccentric elderly ladies who cut up, cook and eat the corpse of an unloved man. The knowing cast of players, sharp dialogue, direction and editing, make this socially observant "gourmet comedy" a feast of macabre fun.

In between the opening and closing films were The Life of Harry Dare, Pat and Eddy's Greyhound Racing Family, That Eye, The Sky, Vacant Possession, Video Fool for Love, and Baby Bath Massacre - the latter shown with Christopher Hinton's short animation Watching TV.

Melbourne came up with four excellent Retrospective Programs: the great Robert Wise (attending with seven films) lightly dismissed by one critic as being known for "his popular hits and minor classics"; director Ritwik Ghatak, one of the true founders, with Ray and Sen, of modern Indian cinema, with his masterwork, The Cloud Capped Star, and his many documentaries and short subjects; Marcel Ophuls (in attendance) and his latest film, The Troubles We've Seen, considering what is truth in the reports of journalists covering the war in Bosnia; Osamu Tezuka, the Japanese animator who created the popular TV series, Astro Boy and Kimba the White Lion; and the inspired surreal-like documentary work of the remarkable Humphrey Jennings.

Known primarily for Listen to Britain (1942) this tribute to him comprised 30 of his films from 1934 until 1950, when he was killed in a rock slide in Greece while scouting locations. At Jennings' funeral, John Grierson (as reprinted in the program) said of him: "No camera has been more distinctive than his. The powerful body of work which now stands to his name represents an achievement of critical significance to all. It demonstrates again, in spite of all the complexities of film making, what the individual vision can bring to the cinema."

Unfortunately - in keeping with others of a like nature travelling around the world's film festivals today many of Melbourne's new films revealed a singular lack of "individual vision." The program staff, lead by the resourceful and knowledgeable Tait Brady, does seem to have a liking for experimental and minimalist cinema which is not terribly good at what it supposedly represents.

This becomes clear when looking at the older experiments in radicalism forming part of the special section given to the showing of Oberhausen's winning films over the festival's past 40 years - short films by Svankma- 
jer, Servais, Polanski, Muller, Gill and Reiffarth, among others. They have few if any equals among today's exponents of the unexpected working in the many fields of expression available to artists in cinema.

The director of Oberhausen, Angela Haardt, came along to talk about New Images for a World in Change. How filmmakers create and interpret images in this computer-generated age making them relevant to society is a challenge few seem capable of meeting. Without Grierson's "individual vision" everything tends to look and sound the same.

The belief among some critics that what is poorly created must be a profound statement was apparent in the surprising response at the festival to three undistinguished Canadian entries: "Avant-gardist director Mike Hoolboom's first feature, Valentine's Day, weaves a confronting tangle of personal pain and national politics" ... "Jeremy Podeswa's fractured mosaic, Eclipse, captures frissons of longing, guilt and regret in an intelligent meditation on love, loneliness and sexuality" ... "Patricia Rozema's When Night is Falling explores in high-flying style the heady terrain of obsession, lust and the resurrective powers of love; a fanciful foray into lipstick lesbian lore it is savvy and sexy as all hell." Well, there is no film so bad that someone, somewhere, doesn't consider it to be a masterpiece. In fairness to Rozema's piece it should be mentioned that an "informal audience poll" gave her the most popular feature film citation. She won the similar audience award in Berlin in February.

Among the remaining Canadian films on the program were Larry Weinstein's September Songs: The Music of Kurt Weill, "ultra-slick and rather pompous, interprets him for the nineties, placing him in his historical context with an appropriate style for each song" ... and the short subjects, most in the avant-garde vein: Drowning in Flames (Garine Torossian), The Evil surprise (François Miron), I Love My Work and My Boyfriend Gave Me Peaches (Anne Marie Fleming), The Pensioner (Yves Belanger), People in the House (Louise Bourque), Rew F Fwd (Denis Villeneuve) and Without Rockets (Gary Yates).

"Floating" narrative lines, "de-psychologised" characterisation and "holistic" interpretations in patterns of behaviour were qualities apparently to be found in many of the entries at the festival, but three films receiving high praise from critics and the public alike seemed free of this critical speculation and none the worse for it. They are Antonia Bird's Priest, Michael Winterbottom's The Butterfly Kiss (both directors in attendance) and Mohammad Ali Talebi's The Boots from Iran.

To paraphrase the Fitzpatrick travel shorts of olden days we leave the magnificent city of Melbourne soaked in winter rain and damp, with its critics struggling with post-colonialism, sexual identities and gender confrontation and return to earth with some reassuring comments by Tait Brady: "I cannot help thinking after seeing The Sentimental Bloke again and watching sequences of it over and over, that today's gadgetry, the wizardry, the complicated sound and special effects, are just icing on the cake of obscure narratives and shallow characters. The reason The Bloke works is because you care about the people, you're engaged by the story and it somehow touches your life."

The 1995 edition of Australia's oldest and largest festival projected 277 films from 35 countries, the total almost equally divided between features and shorts, with a record attendance around 74,000 on a budget of $\$ A 75,000$. While showing the work of American independents it does not believe that Hollywood gala performances should be a part of the festival. Next year the event will have a city centre when it moves into the Regent, a fully restored movie palace from the past seating 2,000 people.

According to Tait Brady, who has been the director for the past seven years, the final months of preparation are always frantic and worrying. As Paul Byrnes, the director of Sydney's Festival says, "getting the films is bloody hard." Brady agrees, but both are dedicated believers who think it's worth it and gratifying. "We've been going for 44 years and I think what we have in Melbourne is a film-literate, enthusiastic and discerning audience for a wide range of cinema.

One of the attractions of movie-going is the 'mystique' surrounding the experience: watching videos at home is a different part of the attraction to the medium. The other part is seeing pictures on the big screen, in the dark, and often with large numbers of people. This is I think a key element of the festival. It's a social event." 


\section{Author Information}

Gerald PRATLEY, OC, LLD, started his career as film critic with the CBC. In 1969, he founded the Ontario Film Institute which he directed until 1990. He has written several books and numerous articles on film, including Torn Sprockets, a history of Canadian cinema. He taught Film History in universities in Toronto and Waterloo, Canada and holds three honorary degrees from Canadian and US universities.

Gerald A. Pratley (1923-2011) was born and educated in London, England, and came to Canada in 1946. He started working in Toronto for the $\mathrm{CBC}$ as a scriptwriter. He was drawn toward working in motion pictures, and became, in 1948, the CBC's first film critic and commentator.

Gerald Pratley broadcast three programmes a week, Pratley at the Movies, The Movie Scene, Music From the Films, and others, until 1975. During this time he also became the first post-war chairman of the Toronto Film Society, chairman of the Toronto and District Film Council and co-founder of the A-G-E Film Society and correspondent for international magazines such as Films and Filming, Film In Review, Variety, Hollywood Quarterly and International Film Guide. During the 1950s he wrote for Canadian Film Weekly and Canadian Film Digest.

He became known as a speaker on all aspects of motion picture art and industry, and was invited to teach film history at the University of Toronto, York University, University of Waterloo, Seneca College and Ryerson Polytechnical University, with individual lectures being given at many other Canadian and US universities and colleges. He has served as a member of various judging panels of competitions and festivals, being one of the members of the first Canadian Film Awards in 1949.

From 1970 to 1975 he was the director of the Stratford (Ontario) International Film Festival, and from 1969 to 1976 he was Chairman of the International Jury of the Canadian Film Awards. He has attended all the world's leading festivals of film, and in particular, for 30 years, the Cannes Festival as CBC correspondent. He has written six books, The Films of Frankenheimer: Forty Years in Film; The Cinema of John Frankenheimer; The Cinema of Otto Preminger; The Cinema of David Lean; The Cinema of John Huston, and Torn Sprockets, a history of the Canadian cinema.

Gerald Pratley has served on the Advisory Boards of the film departments of Ryerson Polytechnical University and Humber College, and as a member of the programme committee of TV Ontario. In 1968 he became the founder-director of the Ontario Film Institute of the Province of Ontario, an organization which has

distinguished itself in archival holdings and public service and is known since 1990 as the Cinematheque of Ontario. He taught Film History courses at the Department of Film and Photography, Ryerson Polytechnic University, Toronto and the University of Waterloo.

In 1984, Gerald Pratley was made a Member of the Order of Canada and in 2003 Officer of the Order of Canada for his service to Canada through film appreciation. He holds Honorary Degrees in Letters and Fine Arts from York and Waterloo Universities (Ont., Canada) and Bowling Green State University (Ohio, USA).

In 2002, Gerald Pratley received a Special Genie Award from the Academy of Canadian Cinema \& Television in recognition of his lifelong dedication to the promotion and his exceptional support of Canadian cinema.

He died on 14 March 2011 in Ontario, Canada. 